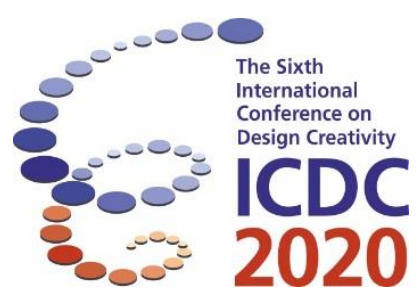

\title{
Necessity of key stakeholder-based role-plays for NPD projects -- A case study for a project team of Non- Industrial Robotics in Japan
}

\author{
Xiang Yu, Jiawei Gao and Yuichi Washida \\ Business School/ Hitotsubashi University, Tokyo, Japan
}

\begin{abstract}
Companies have been increasingly opting to utilize project teams to contend with highly turbulent and dynamic conditions while under current uncertainty markets, stakeholders have tremendous influences on the performance of NPD projects. On the other hand, it is normal that the conflicts between different key stakeholders' interests exists and the new interest may be generated among the NPD progress. Due to these reasons, managing the relationships among the stakeholders in NPD projects is extremely complicated work and thus the key stakeholder-based role-plays may be vital for the NPD performance. In this paper we analyze the dynamic of key stakeholders of the first three stages of the non-industrial robotic NPD in Japan and propose should be performed that the key stakeholder-based role-plays is necessary for the future two NPD stages.
\end{abstract}

Keywords: Stakeholder, NPD, Simulation, Project team, Role-plays

\section{Introduction}

As a core activity to create added value, New Product Development (NPD) ensures stable cash flow by raising stakeholders' expectations (Sorescu et al., 2007; Srivastava et al., 1999; Swink \& Song, 2007). Moreover, due to the development of ICT technology, the acceleration of globalization and the fluctuation of market demand, the uncertainty of NPD is much higher than before (Mitchell \& Nault, 2007). In such uncertain markets, it is difficult to predict the rapidly changing market demand (Eisenhardt \& Tabrizi, 1995), meanwhile the product specifications and the overall directions of the R\&D are frequently changing during the NPD process (Mitchell \& Nault, 2007). Not only factors such as industrial design, environment and manufacturability but also the stakeholders have tremendous influences on the performance of NPD projects (e.g., Nobelius, 2004). Besides, from idea creation to market introduction, NPD consists of several successive stages (Kalyaraman \& Krishnan, 1997; Valle \& Vazquez-Bustelo, 2009), each of which changes the position, interests and importance of stakeholders (Elias et al., 2002; Elias, 2016). That is to say, the key stakeholders involved in each stage of NPD are highly likely to change. Meanwhile, different viewpoints and interests of these gatekeepers may lead to conflicts (Elias et al., 2002). Due to these reasons, managing the relationships among the stakeholders in NPD projects is extremely complicated work (Hall \& Martin, 2005).

Therefore, the project team should identify different key stakeholders, predict their interests in advance and balance their interests in the NPD projects (Driessen \& Hillebrand, 2013; Hill \& Jones, 1992). Therefore, we can say that a key stakeholder-based simulation is needed. However, little attention has been paid on this aspect. Moreover, stakeholder-based simulations have already been used in the area of policy formulation. Because stakeholders involved in policies are very clear and have relatively clearly defined their own interests in advance, it is common to create a causal loop model by 
interviewing key stakeholders and validate it quantitatively. However, in the case of NPD, it is difficult to clearly identify key stakeholders and their stake in advance as it is common that a lot of interests are generated among NPD process. From this point of view, there is a high possibility that the computer simulation used to analyse interests of stakeholders ignore some issues that are vital for NPD.

To bridge the gap discussed above, the structure of this article is as follows. After reviewing previous studies of NPD and stakeholders, we conduct a case study to verify the dynamic of key stakeholders among NPD stages and their most interests are insensible at the beginning of the process. Besides, we propose the importance of role-playing games for NPD.

\section{Literature Review}

\subsection{NPD phases}

The development process model is based on NASA's Phased Project Planning (PPP) method in the 1960s. The development process consists of six phases: idea creation, scaling, business analysis (qualitative and quantitative), prototyping, testing, and market introduction. The evaluation points are set for each phase, and the decision to continue or cancel (Go or Kill) is made. Since then the flow of the research considering market orientation has appeared and it has become a centre theory of product development process (e.g., Clark \& Fujimoto, 1989; Thomke, 1998). Specifically, the NPD process is divided into six stages: identification of opportunities, development of concepts and ideas, product design, process design, product testing, and commercialization. Later, Lioukas (2007) combined product and process design into a single stage called Concurrent Engineering (CE), emphasizing the need for collaboration between design and production engineers.

\subsection{Stakeholder management}

Stakeholders are originally defined by Freeman as a "group or individual that influences or is affected by the achievement of an organizational purpose" (Freeman, 1984, p. 46). Since then, it has gained much attention in various fields such as corporate governance (e.g., Spitzeck \& Hansen, 2010; Letza et al., 2004), public policy (e.g., Spyridaki et al., 2016), industrial policy (e.g., Koontz, 2005), and marketing (e.g., Bhattacharya \& Korschun, 2008). As a classification of stakeholders, a stakeholder map is generally used, in which stakeholder groups are arranged radially around the company and visualized as shown in the left of Figure 1. However, this will only equalize the rights that can be exercised by stakeholders and eliminates differences between stakeholders. Besides, Stakeholders who directly interact with the production of products and services, such as customers, suppliers, employees and investors, are defined as primary stakeholders. Meanwhile communities, governments, social groups, and the public, who have strong interactions and participation relationships with primary stakeholders are defined as secondary stakeholders (Post et al., 2002b; Freeman et al., 2007). Managers are also
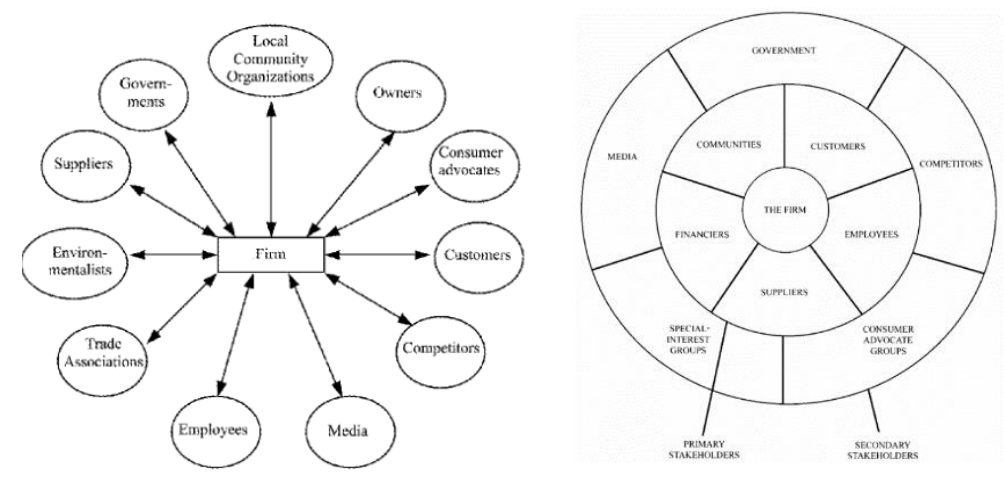

Figure 1. Stakeholder map (Freeman, 1984; Freeman et al., 2007)

stakeholders and are essential to the sustainable development and business survival of the company. (Donaldson \& Preston, 1995; Maignan \& Ferrell, 2004). 
In addition, some studies, such as Freeman (1984), focus on changes in the stakeholder mix over time, that is, the dynamics of stakeholders (e.g., Agle et al., 1999; Elias et al., 2002; Mitchell et al, 1997). According to Freeman (1984), the mix of stakeholder's changes over time, and it is likely that they will enter the organization's stakeholder channel for their interests and then drop out. He also introduced a method for analysing stakeholder management capabilities, consisting of a Rational Level, a Process Level, and a Transactional Level. Specifically, it is necessary to find out stakeholders and create a stakeholder map and analyse each stakeholder's interests and power at a rational level. Moreover, analysing how the organization manages stakeholders' relationships at a process level is needed. After that, it is necessary to analyse the efficiency of project managers' interactions with stakeholders at a transaction level. According to this research, several approaches to creating stakeholder maps and analysing their power were proposed (For instance, see Mendelow, 1981; Johnson \& Scholes, 1999). Since then, Mitchell et al. (1997) pointed out that stakeholders can be identified by three relational attributes: power, legitimacy, and urgency. Power is defined as the extent to which a party has or can gain access to coercive (physical means), utilitarian (material means) or normative (prestige, esteem and social) means to impose their will. Legitimacy is defined as 'a generalized perception or assumption that the actions of an entity are desirable, proper, or appropriate within some socially constructed system of norms, values, beliefs, and definitions'. Urgency is defined as 'the degree to which stakeholder claims call for immediate attention'. He proposed eight stakeholder groups with the above three indicators and proposed a model to analyse the dynamics of stakeholders by capturing changes in the grouping schedule (e.g., Agle et al, 1999; Elias et al., 2002). The Stakeholder typology developed by Mitchell et al. (1997) is shown in Figure 2. Previous studies on stakeholders provided insights into the importance of stakeholders in NPD projects, changes in key stakeholders at each stage of NPD, identification of key stakeholders and conflicts, and evaluation of capabilities to manage stakeholders. However, there are still few methodological frameworks to manage conflicts at each stage of NPD.

\section{Research methodology and analysis}

Our purpose is to find out the key-stakeholder at each NPD stage and to find a way to promote NPD by managing key-stakeholder. Therefore, the purpose of this paper is to outline a process of theory building. Also, stakeholders cannot be studied outside their natural setting of the team. Thus, a case study method is appropriate (Eisenhardt \& Graebner, 2007; Yin, 2017). The research setting is further described below.

\subsection{Research setting}

To examine the exact stages of NPD and key stakeholder at each stage, we conducted an explorative case study of a project team A in one of the largest Japanese multinational imaging and electronics company, Y. From the late 1990s to early 2000s, the company grew to become the largest copier manufacturer in the world. Nowadays, the company is engaging in development, production, sale, and provision of services for imaging, network system solutions, and industrial products. The primary

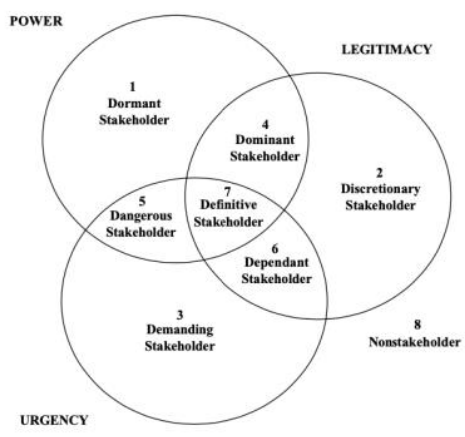

Figure 2. Stakeholder typology developed by Mitchell et al. (1997)

products are cameras and office equipment such as printers, copiers, photocopiers, fax machines and so on. Since 2000, Y begun to acquire and purchase many foreign operations and become a multinational 
corporation with many foreign markets. Because of time restraints, we chose to collect data on team A that focused on the NPD of Non-Industrial Robotics. Team A has already built a prototype and is searching the potential customers to launch their products onto the market. By the case study of team A, not only can we find out the dynamic of key stakeholders at the $R \& D$ process, but we can also try to propose a method to help the market introduction. The data collection and analysis are as follows.

\subsection{Data collection, analysis and results}

Data was gathered from team A in December 2019. The data collection includes two phases. In phase 1 , we used semi-structured interviews with the leader and some members of team A to find out the NPD stages of robot. This is because semi-structured interviews allow us to ask theory-driven questions (Flick, 2018). In phase 2, based on prior related prior studies (Elias et al., 2002; Freeman, 1984; Mitchell et al., 1997), we conduct a systematic stakeholder analysis for this R\&D project which consists of the following four steps: (1) Develop a stakeholder map at each NPD stage; (2) Prepare a chart of specific stakeholders; (3) Identify the stakes of stakeholders; (4) Analyze the dynamics of key stakeholders. The analyses are as follows.

\subsubsection{NPD stages of robot in Japan}

According to the interview, we find that the NPD of team A contains five stages, which is consistent with related prior studies we discussed above. The specific process is provided in Figure 1. Each stage will not begin until the proposal that contains the achievement of current stage's aim, the future aim and needed resources is reported and accepted by the general manager (both Chief of headquarters and Head of department). Team A is at stage 3 currently and will try to enter stage 4 next year. According to the interviews, although the name of the stage may be different, the process proposed in Figure 3 is quite representative of robot development in Japan.

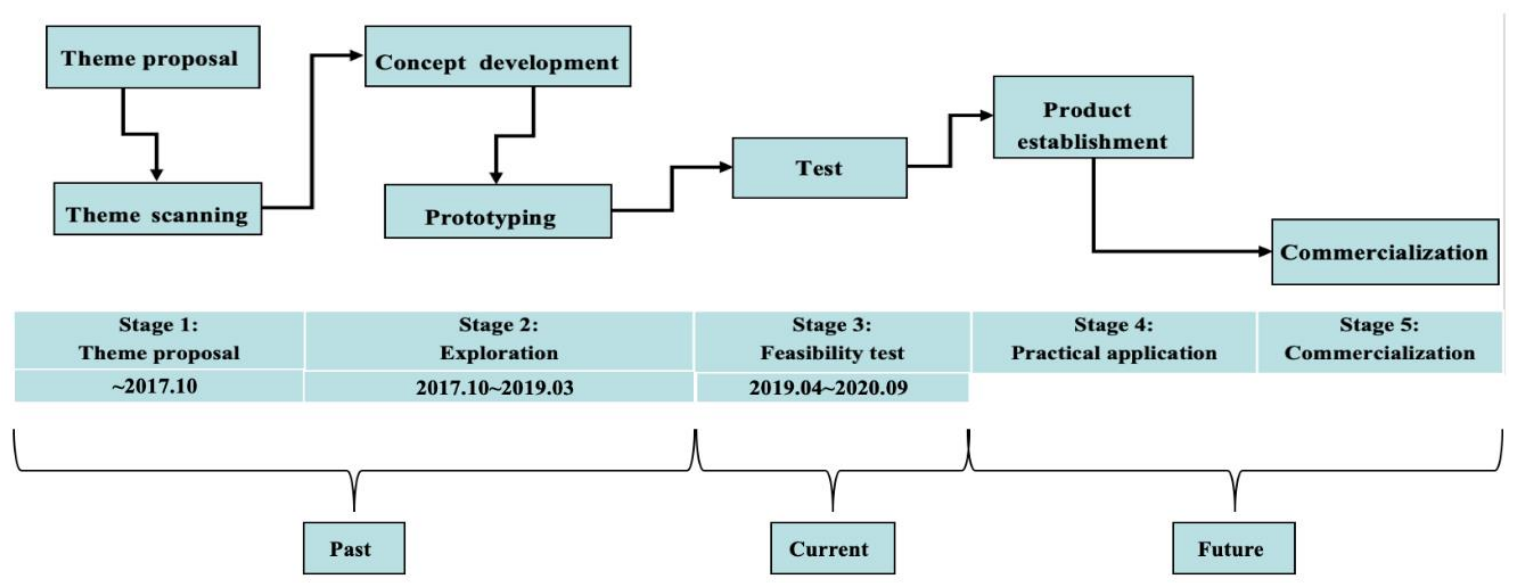

Figure 3. NPD stages of Non-Industrial Robotics project in Team A

\subsubsection{Develop a stakeholder map at each NPD stage}

We start with the semi-structure interview of the history of first three stages at phase 2 so that we can figure out the stakeholder group at each stage. We then develop stakeholder maps of each stages based on the collected interview data. The detail is shown in Figure 4.

\subsubsection{Prepare a chart of specific stakeholders}

We then develop a chart of specific stakeholder based on the the stakeholder map above. Considering the problem of privacy, we show only some parts of specific stakeholders in Table 1. 

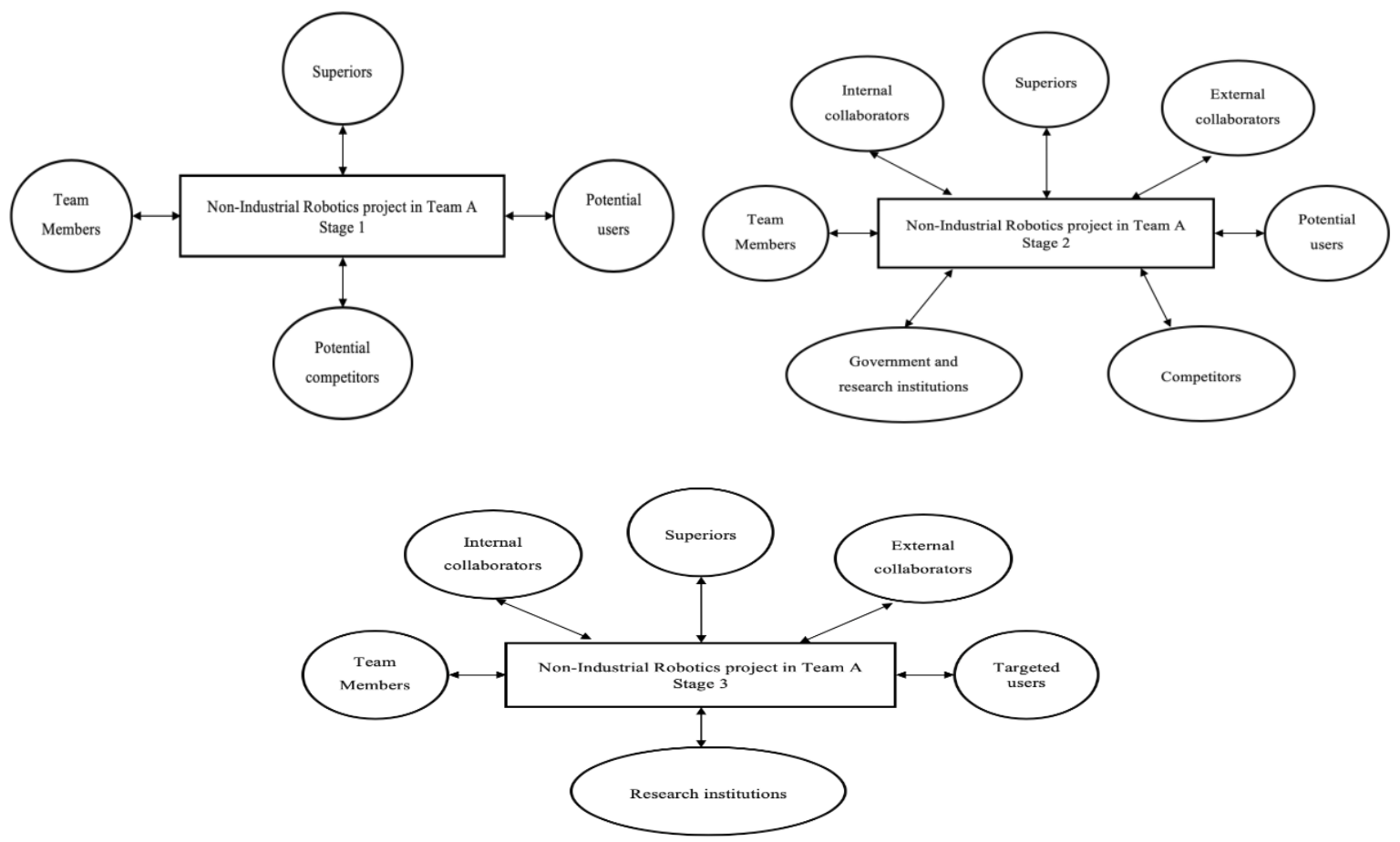

Figure 4. A stakeholder map of the Non-Industrial Robotics project in Team A

Table 1. Specific stakeholder of Non-Industrial Robotics project in Team A

\begin{tabular}{|c|c|c|}
\hline Stage 1 & Stage 2 & Stage 3 \\
\hline \multicolumn{3}{|c|}{$\begin{array}{c}\text { Superiors: } \\
\text { Chief of headquarters; Head of department; Sub manager; Top management... }\end{array}$} \\
\hline \multicolumn{3}{|c|}{ Team Members: } \\
\hline \multicolumn{2}{|c|}{$\begin{array}{c}\text { Potential users: } \\
\begin{array}{c}\text { College; Managers of leading company; small and medium enterprise; } \\
\text { Mayor of city, town, and village... }\end{array}\end{array}$} & $\begin{array}{l}\text { Targeted users: } \\
\text { Hotels; Factories of external } \\
\text { companies; Temple... } \\
\end{array}$ \\
\hline \multirow[t]{4}{*}{$\begin{array}{c}\text { Potential competitors: } \\
\text { Companies which already had } \\
\text { similar products; Companies } \\
\text { which is going similar products... }\end{array}$} & \multicolumn{2}{|c|}{$\begin{array}{l}\text { Internal collaborators: } \\
\text { Other teams in the department; Operations departments; Factories of the } \\
\text { company... }\end{array}$} \\
\hline & \multicolumn{2}{|c|}{$\begin{array}{l}\text { External collaborators: } \\
\text { Suppliers; Affiliated companies; Subsidiary companies; Consultants... }\end{array}$} \\
\hline & \multicolumn{2}{|c|}{$\begin{array}{c}\text { Government and research institutions: } \\
\text { College; National Laboratories; Government; Government related } \\
\text { institutions... }\end{array}$} \\
\hline & $\begin{array}{c}\text { Competitors: } \\
\text { Companies that provide similar } \\
\text { products }\end{array}$ & \\
\hline
\end{tabular}

\subsubsection{Identify the stakes of stakeholders}

Next, we identify and analyze the stakes of the specific stakeholders. In Table 2 we have shown the major stakes of some selected stakeholders.

\subsubsection{Analyze the dynamics of key stakeholders}

After the above steps, we then asked the team leader to answer the questionnaire in order to value the power, legitimacy and urgency of each specific gatekeepers in the chart we proposed above (Mitchell et 
al.,1997). By analyzing the answer of team leader, we find out the definitive stakeholders at first three stages and the list of them is shown in Table 3. This result verifies that the importance of stakeholders does change in the NPD process.

Table 2. Major stakes of some selected stakeholders

\begin{tabular}{|c|c|}
\hline Selected stakeholders & Major stakes \\
\hline Head of department & $\begin{array}{l}\text { Being "the only one" that can meet the unsolved needs of } \\
\text { customers }\end{array}$ \\
\hline Sub manager & Developing advanced technology that not exist \\
\hline $\begin{array}{l}\text { Government/ Government related } \\
\text { institutions }\end{array}$ & Safe robot that can promote the efficient usage of social resources \\
\hline Operations departments & $\begin{array}{l}\text { Sales and profit promotion by introducing business of the non- } \\
\text { industrial robot }\end{array}$ \\
\hline Suppliers & Sales and profit promotion by supplying the technologies or parts \\
\hline
\end{tabular}

Besides, to find the key relationships and dynamics that had already emerged across the team in first three stages, we then interviewed the leader and two team members in the team. The results are as follow. At the first stage, the team leader had to combine the market information including needs, technologies and competitors gathered by other members to come up a new proposal. Besides, he often discussed with the sub manager as he had a good relationship with head of department, who had the authorities to decide the "Go or kill" of the proposal and the budgets the team can get. For example, the leader said that he had to spend a lot of time and energy to revise the proposal in a way that meet the sub manager's stakes as the sub manager had a belief that the most vital thing for teams to survive is developing advanced technology while the team leader believes that the starting point should be market needs. At the next stage of concept development and prototyping, the head of department and chief of the headquarter become key stakeholders and not only did the team leader have to report to sub manager, but he also needed to report to the head of department and chief of the headquarter. According to the team leader, he was extremely exhausted as these three supervisors had different stakes and the leader spent a lot of time to make the direction of current project meet all of three supervisors, which, made the project less efficiency and caused a 6-month delay. As for stage 3, the target users become vital as the team had to test their prototype in the real conditions so that they can find potential markets they may enter and revise prototype to meet specific needs of these potential users. The leader also said that he had to report the results of the interview of external users and field test to his three supervisors we mentioned above and try to combine the stakes of them. This can be very difficult sometimes since the target users' needs or stakes are opposite to the supervisors. We also interview them about the perspective about future two stages. According to their answers, they believe that it is highly possible that the operations departments and external target users become key stakeholders as the successfully practical application and commercialization need to count on operations departments as well as target users, which, means their stakes will become the priority of the team.

Table 3. key stakeholders in first three stages of the Non-Industrial Robotics project

\begin{tabular}{|c|c|c|}
\hline Stage 1 & Stage 2 & Stage 3 \\
\hline Team leader & Team leader & Team leader \\
Sub manager & Sub manager & Sub manager \\
& Head of department & Head of department \\
& Chief of the headquarters & Chief of the headquarters \\
& & Targeted users \\
\hline
\end{tabular}

\subsubsection{The necessity of key stakeholder-based role-plays in NPD process}

After reporting the above analysis to the team members, we then interviewed them to find out the difficulties to manage conflicts among these key stakeholders. According to their answers, we find that the team spent a lot of energy and time dealing with these conflicts as they can't predict the interests of 
key stakeholder that newly generated among the NPD process in advance. Considering that current methods of computer simulation are not suitable to deal with this subjective problem, we propose that a key stakeholder-based role-plays should be developed for NPD projects.

\section{Discussion}

\subsection{Implications}

Our research propose that predict conflicts in stakeholders' group at each NPD stages and find a way to manage them in advance can lead the NPD process more efficiency, which, can save members more time and energy from dealing with these conflicts and less stressed. Considering that more time and energy that devoted to the project and less stressed working condition is necessary conditions for members' creativity (Amabile et al., 1996), we believe that our research do have a potential contribution on creativity. Besides, as demonstrated by prior research, companies have been increasingly opting to utilize NPD teams to promote innovations performance at current highly turbulent and dynamic conditions (Taylor \& Greve, 2006). Thus, it is reasonable for us to expect that our research will have potential managerial implications that give companies a direction to promote the performance of their innovation activities. Although due to the time constraints we were only able to do one case study, we believe that our results are also suitable for other Japanese NPD teams as they all have the similar characteristic that the potential key stakeholders are highly likely to change and very difficult to predict (Elias et al., 2002; Elias, 2016). Also, although conflicts in the NPD process is an interesting topic, the prior work has a limited literature to offer in managing conflicts in stakeholders' group that can be extended to NPD. Thus, we expect that this research can contribute to current literature by providing a new direction in which a key stakeholder-based role-plays should be developed to better manage the conflicts of key stakeholders at NPD process.

\subsection{Limitations and future tasks}

We haven't developed key stakeholder-based role-plays as the time is restrained and the project of our research subject haven't finished. Also, considering that creating a reliable key stakeholder-based roleplays request large amounts of data to refine it, we thus expect further researchers to set up more studies in order to gather data.

\section{References}

Agle, B. R., Mitchell, R. K., \& Sonnenfeld, J. A. (1999). Who matters to Ceos? An investigation of stakeholder attributes and salience, corpate performance, and Ceo values. Academy of management journal, 42(5), 507-525.

Amabile, T. M., Conti, R., Coon, H., Lazenby, J., \& Herron, M. (1996). Assessing the work environment for creativity. Academy of management journal, 39(5), 1154-1184.

Bhattacharya, C. B., \& Korschun, D. (2008). Stakeholder marketing: Beyond the four Ps and the customer. Journal of Public Policy \& Marketing, 27(1), 113-116.

Clark, K., \& Fujimoto, T. (1989). Reducing the time to market: The case of the world auto industry. Design Management Journal, 1(1), 49-57.

Donaldson, T., \& Preston, L. E. (1995). The stakeholder theory of the corporation: Concepts, evidence, and implications. Academy of management Review, 20(1), 65-91.

Driessen, P. H., \& Hillebrand, B. (2013). Integrating multiple stakeholder issues in new product development: an exploration. Journal of Product Innovation Management, 30(2), 364-379.

Eisenhardt, K. M., \& Graebner, M. E. (2007). Theory building from cases: Opportunities and challenges. Academy of management journal, 50(1), 25-32.

Elias, A. A. (2016). Analysing the stakes of stakeholders in research and development project management: a systems approach. R\&D Management, 46(4), 749-760.

Elias, A. A., Cavana, R. Y., \& Jackson, L. S. (2002). Stakeholder analysis for R\&D project management. $R \& D$ Management, 32(4), 301-310.

Freeman, R. E. (1984). Strategic management: A stakeholder approach. Marshfield, Massachussets, Pitman Publishing, Inc.

Freeman, R. E. (2010). Strategic management: A stakeholder approach. Cambridge university press. 
Freeman, R. E., Harrison, J. S., \& Wicks, A. C. (2007). Managing for Stakeholders: Survival, Reputation and Success. Yale University Press: New Haven, CT.

Flick, U. (2018). An introduction to qualitative research. Sage Publications Limited.

Hall, J. K., \& Martin, M. J. (2005). Disruptive technologies, stakeholders and the innovation value - added chain: a framework for evaluating radical technology development. R\&D Management, 35(3), 273-284.

Hill, C. W., \& Jones, T. M. (1992). Stakeholder-agency theory. Journal of management studies, 29(2), 131-154.

Hillebrand, B., Driessen, P. H., \& Koll, O. (2015). Stakeholder marketing: theoretical foundations and required capabilities. Journal of the Academy of Marketing Science, 43(4), 411-428.

Johnson, G., \& Scholes, K. (1999). Exploring corporate strategy. London: Prentice Hall Europe.

Kalyaraman, G., \& Krishnan, V. (1997). Deliberate product definition: Customizing the product definition process. Journal of Marketing Research, 34(2), 276-285.

Koontz, T. M. (2005). We finished the plan, so now what? Impacts of collaborative stakeholder participation on land use policy. Policy studies journal, 33(3), 459-481.

Letza, S., Sun, X., \& Kirkbride, J. (2004). Shareholding versus stakeholding: A critical review of corporate governance. Corporate Governance: An International Review, 12(3), 242-262.

Lioukas, S. (2007). Concurrent Engineering: Strategy for Effective Product Development Team to Achieve and Sustain Company's Objective. Harvard Business Review, 85(3), 94-102.

Maignan, I., \& Ferrell, O. C. (2004). Corporate social responsibility and marketing: An integrative framework. Journal of the Academy of Marketing science, 32(1), 3-19.

Mitchell, R. K., Agle, B. R., \& Wood, D. J. (1997). J. Towards a theory of stakeholder identification and salience: Defining the principle of who and what really counts. Academy of Management Review, 22(4), 853-886.

Mitchell, V. L., \& Nault, B. R. (2007). Cooperative planning, uncertainty, and managerial control in concurrent design. Management Science, 53(3), 375-389.

Nobelius, D. (2004). Towards the sixth generation of R\&D management. International Journal of Project Management, 22(5), 369-375.

Olander, S., \& Landin, A. (2005). Evaluation of stakeholder influence in the implementation of construction projects. International journal of project management, 23(4), 321-328.

Pahl-Wostl, C. (2002). Participative and stakeholder-based policy design, evaluation and modeling processes. Integrated assessment, 3(1), 3-14.

Post, J. E., Preston, L. E., \& Sauter-Sachs, S. (2002). Redefining the corporation: Stakeholder management and organizational wealth. Stanford University Press.

Reijs, J. (1994). Foresight studies undertaken by the Ministry of Economic Affairs in the Netherlands. $R \& D$ Management, 24(2), 167-174.

Sorescu, A. B., \& Spanjol, J. (2008). Innovation's effect on firm value and risk: Insights from consumer-packaged goods. Journal of Marketing, 72(2), 114-32.

Sorescu, A., Shankar, V., \& Kushwaha, T. (2007). New product preannouncements and shareholder value: Don't make promises you can't keep. Journal of Marketing Research, 44(3), 468-89.

Spitzeck, H., \& Hansen, E. G. (2010). Stakeholder governance: how stakeholders influence corporate decision making. Corporate Governance: The international journal of business in society, 10(4), 378-391.

Spyridaki, N. A., Banaka, S., \& Flamos, A. (2016). Evaluating public policy instruments in the Greek building sector. Energy Policy, 88, 528-543.

Srivastava, R. K., Shervani, T. A., \& Fahey, L. (1998). Market-based assets and shareholder value: a framework for analysis. Journal of Marketing, 62(1), 2-18.

Swink, M., \& Song, M. (2007). Effects of marketing-manufacturing integration on new product development time and competitive ad- vantage. Journal of Operations Management, 25(1), 203-17.

Thomke, S. H. (1998). Managing experimentation in the design of new products. Management Science, 44(6), 743-762.

Taylor, A., \& Greve, H. R. (2006). Superman or the fantastic four? Knowledge combination and experience in innovative teams. Academy of Management Journal, 49(4), 723-740.

Valle, S., \& Vazquez-Bustelo, D. (2009). Concurrent engineering performance: Incremental versus radical innovation. International Journal of Production Economics, 119(1), 136-148.

Winn, M.I., \& Keller, L.R. (2001). A Modeling Methodology for Multiobjective Multistakeholder Decisions: Implications for Research, Journal of Management Inquiry, 10(2), 166-81.

Yin, R. K. (2017). Case study research and applications: Design and methods. Sage publications. 